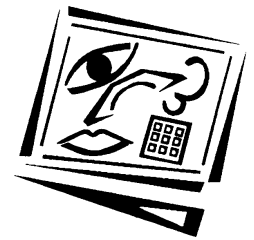

\title{
Empirical validation of the importance of employees' learning motivation for workplace e-learning in Taiwanese organisations
}

\author{
Hsiu-Ju Chen and Chia-Hung Kao \\ I-Shou University, Taiwan
}

E-learning systems, adopted by organisations for employee training to enhance employees' performance, are characterised by self-directed, autonomous learning. Learning motivation is then of importance in the design of e-learning practices in workplace. However, empirical study of the alignment of e-learning with individual learning needs and organisational goals is an area with limited research. This study intends to clarify the importance of learning motivation in employees' e-learning systems use behaviour, based on the information systems success model. Data from one hundred and eighty-five employees who used e-learning systems in their work environment were gathered in Taiwan and analysed with PLS. Results showed that employees' learning motivation, reflecting their learning needs and strengths, influenced perceived usefulness and satisfaction with e-learning, and their use of the systems, which enhanced their task performance. The results validated the importance of employees' learning motivation and the need for alignment of employees' learning needs and organisational goals in e-learning training. The clarification can help facilitate an organisation's human capital management, and contributes to further advancement of the information systems success model.

\section{Introduction}

In a competitive environment, finding ways to use employee training and learning to help enterprises to adapt to changes the external environment is an important issue. With the prospect of cost-effective investment in e-learning training, many enterprises have adopted e-learning systems for employee training to assist in their human capital management in recent decades (e.g. Wang, Wang \& Shee, 2007). Through use of elearning systems, employees can transfer what they have acquired from the training to their jobs and thereby increase their productivity (e.g. Chen, 2010). This helps employees' renewals of knowledge and skills while also reducing knowledge gaps between what the organisations have and what they need in keeping competitiveness.

However, e-learning in workplaces still remains a fragmented, complex, and challenging area (Wang, 2011). The impact of organisational training contexts on new entrants' e-learning training has been verified, but e-learning in workplaces is still confronted with a highly complex set of factors, such as learners, activities, outcomes, etc. (Chen, 2012; Collin, 2006; Wang, Ran, Liao \& Yang, 2010). The alignment of the learning with employees' individual learning needs and organisational goals in a systemic way also lacks clarification in existing studies (Collin, 2006; Wang et al., 2010). E-learning provides learning more learner-centred than instructor-oriented, and workplace learning involves adult learning that emphasises employees' rational 
motivation in learning to meet their needs. Learning motivation which indicates human stimulated needs driving individuals to act to meet those needs, is then of importance in the design of e-learning practices for employees' self-directed learning in work environments (Cross, 1982; Houle, 1979; Rubenson, 1991). Consequently, it raises an important issue clarifying the impact of learning motivation on employees' elearning training.

The information systems (IS) success model, which captures both the technological dimension and the human dimension of human use of information systems/services, provides a systematic theoretical foundation for investigating employees' learning outcomes from e-learning systems (DeLone \& McLean, 2003; Seddon, 1997; Wang et al., 2007; Wu \& Wang, 2006). This study is therefore theory based on a model for empirical clarification of the impact of learning motivation in employees' e-learning training. It provides a theoretical basis reflecting the impact of employees' other perceived net benefits involved in e-learning system usage (Seddon, 1997; Seddon \& Kiew, 1996). This study therefore adopts this model to clarify the importance of learning motivation in employees' self-directed, autonomous e-learning training for productivity. The clarification seeks to improve understanding of employees' elearning use in the changed training environment in workplaces, and also the alignment of the learning with employees' learning needs and organisational goals in e-learning training.

\section{Literature background}

\section{E-learning systems for employee training}

E-learning refers to learning experiences gained through use of information technology, and focuses on the broadest view of learning that goes beyond the traditional learning paradigms (Rosenberg, 2006; Tsai, Shih \& Feng, 2008). It is also characterised by self-directed, autonomous learning, which refers to the process whereby learners systematically achieve learning goals by themselves (Markus \& Wurf, 1987; Schunk \& Zimmerman, 1994). Through e-learning systems, learners can study course contents in an independent manner. They can also decide when to study, the sequence of the content to study, and the amount of time to spend for selfeducation, without time and space barriers (e.g. Blake \& Butcher-Green, 2009; Newton \& Doonga, 2007).

Recently, e-learning systems have been increasingly adopted by organisations for employee training for cost reduction reasons. In workplaces, employees are adults who have good self-concept, and usually they have a clear understanding of their learning needs and can learn independently (Eggen \& Kauchak, 1994; Slavin, 1994). Employees are then expected to increase their performance through undertaking selfdirected, autonomous e-learning training. However, current development of elearning tends to focus on technical issues of design, and most e-learning applications may not perform well in motivating users to learn (Wang et al., 2010). Conflicts between an organisation's aim to invest in e-learning systems for human capital management and employees' needs for renewal of knowledge and skills may then arise if the alignment of the learning with individual learning needs and organisational goals is not achieved (Wang et al., 2010).

Learning motivation has been shown to be important in learning behaviour and learning outcomes in a largely independent environment (e.g. Chen \& Chih, 2011; 
Houle, 1979; Tempelaar, Gijselaers, Van de Loeff \& Nijhuis, 2007). It refers to learners' activating force to choose learning goals and perform in a way that will achieve these goals; it also indicates the extent to which their needs will be met by performing the activity (Cross, 1982; Rubenson, 1991). Task performance indicates the outcomes that organisations expect from employees when performing their tasks (Borman \& Motowidlo, 1993; Kirkpatrick, 1994; Wang et al., 2010). Thus, to clarify the alignment of e-learning with employees' learning needs and organisational goals in self-directed, autonomous e-learning training, this study is motivated to validate the impact of learning motivation upon employee use of e-learning systems in workplaces.

\section{The IS success model}

To indicate the success of information systems (IS), DeLone and McLean (1992) conducted a comprehensive review of IS success literature and proposed the IS success model. Ten years later, they proposed an updated IS success model recognising ecommerce environments, and the basic structure is similar to that of its original model (DeLone \& McLean, 2003). However, to clarify the combined process and causal explanations of the IS success model of DeLone and McLean (1992), Seddon (1997) proposed another adaptation of the model. He took part of the model into the process and variance model: the partial behavioural model of IS use and the IS success model, and then linked the two models with a construct: the individual, organisation, and societal consequences of IS use. The model is shown in Figure 1.

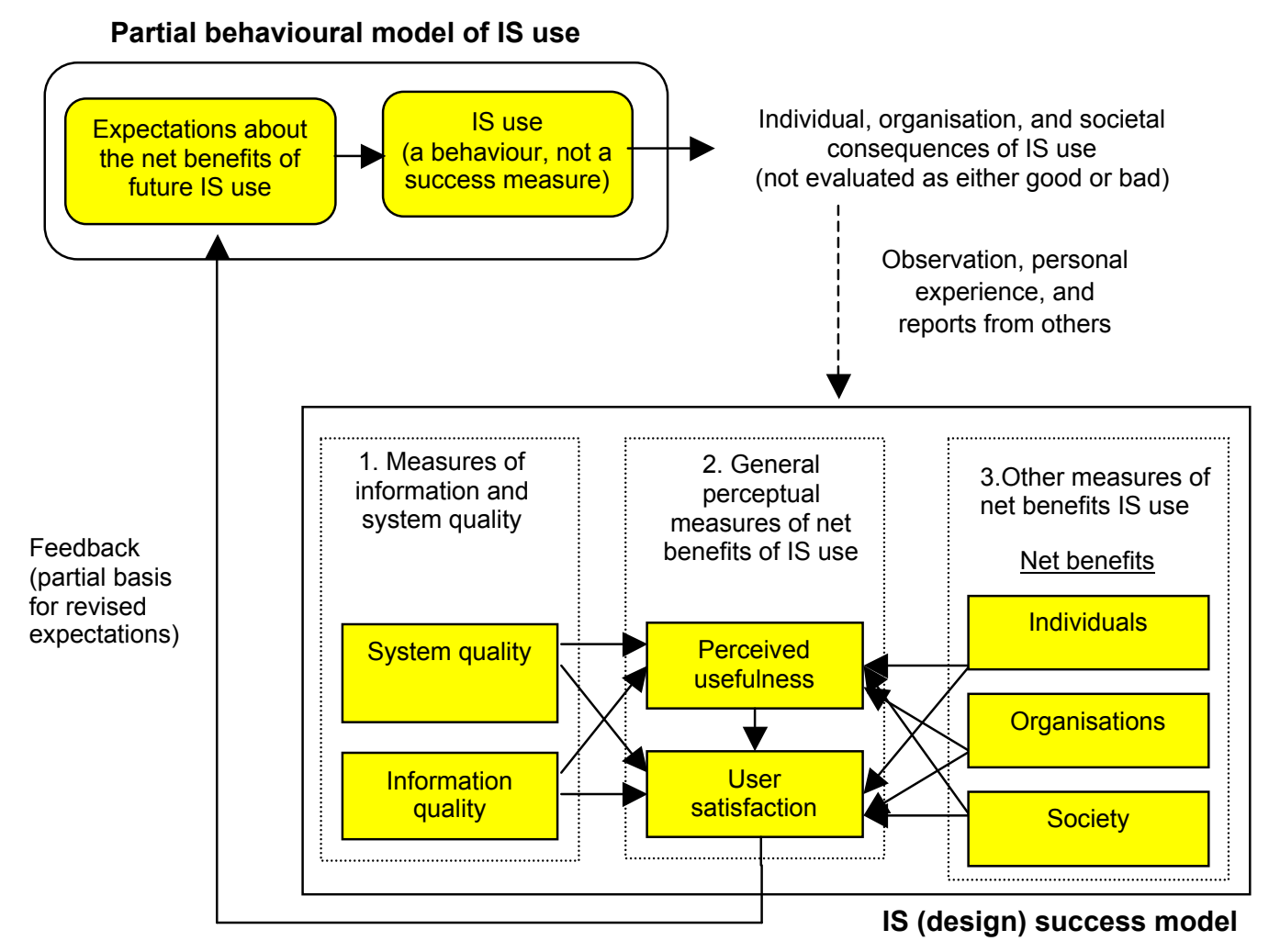

Figure 1: The re-specified IS success model of Seddon (1997) 
The adapted IS success model by Seddon (1997) explains the relationship between the process and variance models in the original IS success model, while still reflecting the essential values of the original model by DeLone and McLean (1992). Besides, it adds the dimension of perceived usefulness, reflecting users' perceived instrumental value of information systems, and indicates the possibility of other constructs to improve the use of the system through perceived usefulness and user satisfaction (Seddon, 1997; Seddon \& Kiew, 1996). This study is thus theoretically constructed based on the model for empirical clarification of the impact of learning motivation in employees' elearning training.

\section{Characterising the importance of learning motivation in employees' e-learning}

Cognitive psychologists elaborate that the occurrence of learning lies in changes of the inner psychological structure of learners who choose to give meaning to the learning experience; an environment only provides potential stimulus to encourage learning (Bandura, 1977). Thus, learners play a key role in learning. A learner's inner psychological structure refers to a learner's cognition of natural and social world and exists in the form of symbols. When new experiences change a learner's inner psychological structure, learning occurs. In order to make learning occur, it is helpful to provide general principles in an appropriate context to match learners' inner psychological structure and assist them in applying what they have learned to new problems (Bandura, 1977; Gredler, 1992; Griffin \& Griffin, 1996; Roblyer, 2004).

E-learning provides modern learning that is more learner-centred than lecturercentred (Lee, Yoon \& Lee, 2009; Tsai et al., 2008). Employees thus have greater control over their learning/training process through e-learning. By using various forms of symbols, e-learning systems may provide simulation courses for employee training; they may also provide courses introducing general rules or specific knowledge for employees to learn. And through the use of these systems, trainees may give meaning to their learning experience; by so doing, they can change their inner psychological structures. Learning then occurs and assists trainees to apply what they have learned to their tasks (Gredler, 1992; Bandura, 1977; Griffin \& Griffin, 1996; Roblyer, 2004).

In workplaces, e-learning systems are expected to provide general principles to match employees' inner psychological structure for training. Employees can then use the systems to learn independently and autonomously, and decide on when to use them to accomplish their learning goals. When they give meaning to the experiences, their inner psychological structure changes and learning occurs. Thus, if employees are willing to accept the systems and take responsibility for their training, the change in their inner psychological structure aids their training/learning transfer to work, as expected in employee training (Chen, 2010; Chen, 2012; Wexley \& Latham, 1981).

Motivation indicates human stimulated needs that drive individuals to act, in order to meet those needs (Cross, 1982; Houle, 1979; Rubenson, 1991). It also reflects an individual's expected value for an activity. The higher the expected value is, the stronger the degree that needs can be met by performing that activity. In andragogy, learning motivation also drives an adult's voluntary learning and active participation in learning/training activities (Houle, 1979; Tempelaar et al., 2007). It refers to an activating force leading individuals to choose learning/training goals and perform in a way that will achieve these goals. With expectations by reason of the learning value, the force, i.e. the strength of behaviour, is determined (Cross, 1982; Rubenson, 1991). 
In Seddon's (1997) IS success model, it indicates the possible impact of other net benefits of individuals, organisations, and society on users' perceived usefulness and user satisfaction, which motivate them to use information systems/services. The study by Seddon and Kiew (1996) also demonstrates empirically that user involvement, reflecting users' opinions about the relevance of the system to their own goals, influences their perception of the system as useful and satisfying. Later, Fraser and Salter's study (1995), being similar to that of Seddon and Kiew's (1994), provides consistent results. User involvement refers to users' subjective psychological state that reflects the importance or relevance of specific or general information systems to them. Learning motivation is also a subjective psychological state which indicates users' expected value in performing learning activities, and drives adults' voluntary learning and active participation in training activities (Boshier, 1978; Houle, 1979; Pintrich, 1987; Pintrich \& DeGroot, 1990). As a result, if employees are willing to take responsibility for their own learning, their perceptions of the system's usefulness and user satisfaction increase and motivate their further use of e-learning systems that aids their training/learning transfer to work (Chen, 2010; Chen, 2012; Wexley \& Latham, 1981). Therefore, based on the IS success model, this study intends to empirically clarify the impact of learning motivation on the users' perceived usefulness and user satisfaction in their e-learning system use.

\section{Research hypotheses}

The connection of the technological dimensions and human dimensions of e-learning systems: Information quality, system quality, perceived usefulness, and user satisfaction

In general, e-learning systems provide content for user learning through various media. However, current developments tend to focus on technical issues of design regarding information technology (Wang et al., 2010). From the socio-technical viewpoint, both the technological dimensions (i.e., system quality and information quality) and the human dimensions (such as perceptions of usefulness and user satisfaction) should be captured in the IS success model (Wu \& Wang, 2006). Hence, based on the re-specified IS success model (Seddon, 1997; Wu \& Wang, 2006), the following hypotheses are proposed.

H1: Employees' perception of technological quality is significantly associated with their perceived system use motivation of e-learning systems.

H1a: Employees' perception of information quality is significantly associated with their perceived usefulness of e-learning systems.

H1b: Employees' perception of information quality is significantly associated with their user satisfaction with e-learning systems.

H1c: Employees' perception of system quality is significantly associated with their perceived usefulness of e-learning systems.

H1d: Employees' perception of system quality is significantly associated with their satisfaction with e-learning systems.

Perceived usefulness and user satisfaction in motivating e-learning system use

Through e-learning systems that implement and support training, employees gain knowledge, skills and a new attitude regarding their jobs. Without understanding the benefits (i.e. perceived usefulness and user satisfaction), employees may not use the system. They could be kept from obtaining important information or knowledge, and 
be left with no clear direction on how to move on in their jobs. In the IS success model, both usefulness and user satisfaction are shown to be important perceived benefits that motivate users' system use (Chen, 2012; Wang et al., 2007; Wu \& Wang, 2006). Furthermore, perceived usefulness, indicating users' extrinsic motivator for instrumental value in using computer technology, impacts upon user satisfaction (Davis, Bagozzi \& Warshaw, 1992; Venkatesh, 2000). Therefore, hypotheses about perceived usefulness, user satisfaction, and system use are proposed as follows.

H2: Employees' perceived system use motivation and use of e-learning systems are significantly interrelated.

H2a: Employees' perceived usefulness is significantly associated with their use of elearning systems.

H2b: Employees' user satisfaction is significantly associated with their use of elearning systems.

H2c: Employees' perceived usefulness is significantly associated with their user satisfaction of e-learning systems.

Perceived net benefits aroused by e-learning system use

Literature has shown that employees who are well trained also have good job performance (Whitfield, 2000). Although the evaluation of employees' training outcomes, or the means by which the effect (or value) of trainees' training on the business or environment is measured, such as through increased sales and improved productivity, is important, the objective measurement of net benefits of information systems, such as cost reduction or increased sales, may be lacking because of environmental intervention and intangible system impact (Kirkpatrick, 1996; Wang et al., 2010; Wu \& Wang, 2006). Therefore, users' perceptions are commonly adopted as a measurement of the beneficial consequences from system use, in empirical studies based on the IS success model (Chen, 2010, 2012; Wang et al., 2007; Wang et al., 2010; Wu \& Wang, 2006).

Task performance indicates the outcomes that organisations expect from employees when performing their tasks (Borman \& Motowidlo, 1993; Kirkpatrick, 1994; Wang et al., 2010). Employees' task performance is then not only adequate to be measured as an outcome of employees' use of e-learning systems but also an adequate goal that organisations quest for in employees' e-learning training. Therefore, the following hypothesis is proposed.

H3: Employees' use of e-learning systems is significantly associated with their task performance.

The impact of learning motivation

Finally, Seddon's (1997) IS success model indicates the possible impact of other net benefits on users' perceived usefulness and user satisfaction, which motivate them to use the system. If employees are willing to take responsibility for their learning, their perceptions of e-learning system's usefulness and user satisfaction increase and motivate their further use of the system. Therefore, based on the IS success model, this study intends to attest to the impact of employees' learning motivation on their perceived usefulness and user satisfaction with e-learning systems. 
In addition, learning motivation drives adults' voluntary participation in training activities (Boshier, 1978; Houle, 1979). It refers to an activating force leading individuals to perform learning activities and thus can affect users' use of e-learning systems directly (Pintrich, 1987; Pintrich \& DeGroot, 1990). Therefore, this study also clarifies the impact of learning motivation on systems usage. The following hypotheses are proposed.

H4: Employees' learning motivation improves their perceived system use motivation of e-learning systems.

H4a: Employees' learning motivation improves their perceived usefulness of elearning systems.

H4b: Employees' learning motivation improves their user satisfaction of e-learning systems.

H5: Employees' learning motivation is positively associated with their use of elearning systems.

The conceptual research model for this study is shown in Fig. 2.

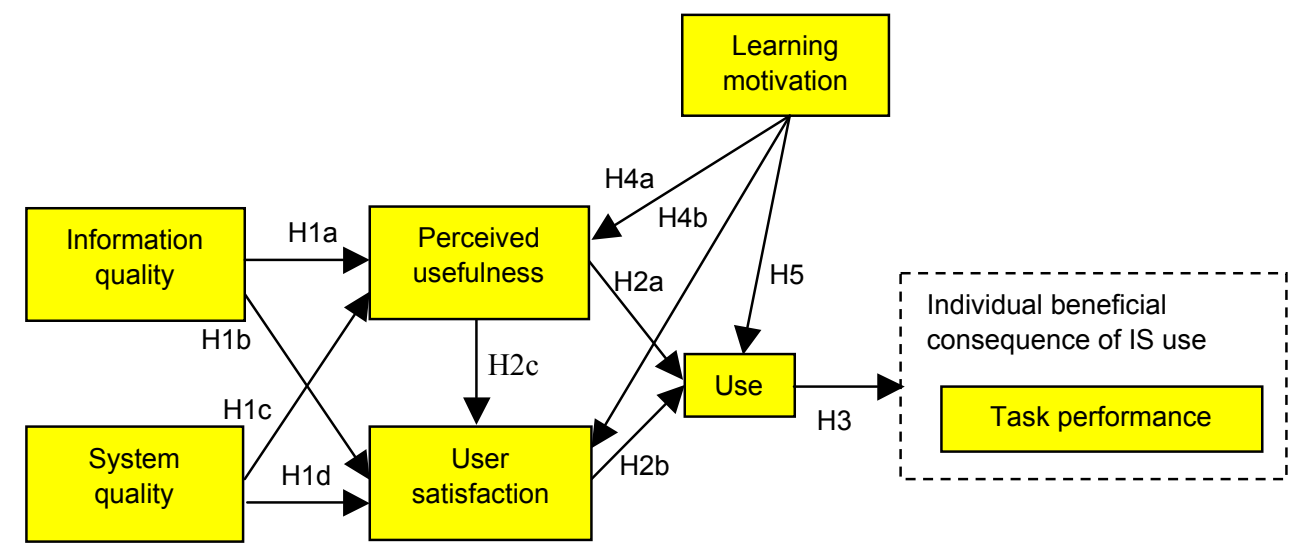

Figure 2: The conceptual research model

\section{Research method}

\section{Measurements}

In order to validate the impact of employees' learning motivation in their use of elearning in workplaces, this study adopted the survey method. The construct measurements included: learning motivation, information quality, system quality, perceived usefulness, user satisfaction, system use, and task performance. All construct measures and operational definitions were based on existing instruments and literatures. All measurements were self-reported by employees, using a Likert seven-point scale ranging from (1) strongly disagree to (7) strongly agree. For measuring task performance, the measurement of users' perception was also adopted for the lack of objective measurement of net benefits from the information systems (Wu \& Wang, 2006). Among different assessments of performance measures, self evaluation by the employees was still acceptable and a valuable reference (Campbell, Dunnette, Lawler \& Weick, 1970; Shore \& Thornton, 1986), and was therefore adopted 
in this study. The operational definitions for each construct are described below, and pertinent questions are listed in Appendix A.

Information quality and system quality

The general definitions and measures of both information and system qualities in traditional IS studies were adopted in this study. Information quality indicates the users' perception of completeness, adequateness, and clarity of the information and format in the output of e-learning systems (Wu \& Wang, 2006; Rai, Lang \& Welker, 2002). System quality was defined as users' perception of easy operation, responsiveness and stability in using the systems (Chen, 2010; Wang et al., 2007).

Perceived usefulness, user satisfaction, and system use

The measures of the constructs of perceived usefulness, user satisfaction, and system use were mainly based on the studies of Seddon and Kiew (1996), Rai, Lang and Welker (2002), and $\mathrm{Wu}$ and Wang (2006). The operational definition of perceived usefulness refers to users' perception of using e-learning systems to improve their job performance. User satisfaction was defined as users' overall satisfaction with elearning systems, and system use indicates users' use and dependence on e-learning systems.

\section{Self-evaluated task performance}

With the diversity of courses provided by e-learning systems, this study adopted task performance to measure the benefits of e-learning systems use. Task performance is defined as the outcomes that organisations expect from employees when performing their tasks (Borman \& Motowidlo, 1993; Kirkpatrick, 1994). The measurement was based on Borman \& Motowidlo (1993), and was self-evaluated by employees (Shore \& Thornton, 1986; Campbell et al., 1970).

Learning motivation

Many studies have clarified the origins of learning motivation and also empirically verified learning motivation of adults (e.g., Boshier, 1978; Cross, 1982; Kao, 2009; Pintrich \& Schunk, 2002; Rubenson, 1979). While most measurements measure adult motivation for continuous education, e-learning systems adopted by organisations are for employee training. Therefore, in exploring the impact of learning motivation in employees' use of e-learning systems, this study adopted the three constructs: professional advancement, learning achievement and influence of others, based on definitions from the literature. The measurements adopted in this study were mainly based on studies by Boshier (1978), Morstain and Smart (1974), and Cross (1982).

The questionnaire was established prior to a formal survey. The pre-study results from twenty respondents indicated that the measures could be easily understood. The questionnaire was then used in the formal survey. The questions are shown in Appendix A.

\section{Data collection}

To gather data, questionnaires were issued to organisations that had publicly announced their investment in e-learning systems, or had applied governmental subsidies to adopt e-learning systems in Taiwan, such as banks, governments, hightech manufacturers, etc, in a period over two months. Because some respondents indicated that they did not use e-learning systems at work, only those organisations whose employees indicated that they actually used e-learning systems in their jobs 
were targeted. In the questionnaire, respondents were asked to answer questions based on their most frequently used e-learning system. In order to attract valid respondents, this study provided valuable coupons for drawing lots. Of about three hundred questionnaires issued, a total of one hundred and eighty-five were validated. Descriptive statistics are given in Table 1.

Table 1: Descriptive statistics $(\mathrm{N}=185)$

\begin{tabular}{|c|c|c|c|}
\hline \multicolumn{2}{|c|}{ Description } & Frequency & Percent \\
\hline \multirow[t]{2}{*}{ Gender } & Male & 106 & $57.3 \%$ \\
\hline & Female & 79 & $42.7 \%$ \\
\hline \multirow{3}{*}{$\begin{array}{l}\text { Years of computer } \\
\text { use }\end{array}$} & Less than 5 years & 21 & $11.4 \%$ \\
\hline & 6-10 years & 62 & $33.5 \%$ \\
\hline & Above 10 years & 102 & $55.1 \%$ \\
\hline \multirow[t]{3}{*}{ Education } & High school & 20 & $10.8 \%$ \\
\hline & College/ university & 117 & $63.2 \%$ \\
\hline & Graduate school (above) & 48 & $25.9 \%$ \\
\hline \multirow{4}{*}{$\begin{array}{l}\text { Organisation } \\
\text { employee numbers }\end{array}$} & Below 100 & 30 & $16.2 \%$ \\
\hline & $100-499$ & 30 & $16.2 \%$ \\
\hline & 500-1999 & 16 & $8.7 \%$ \\
\hline & 2000 or more & 109 & $58.9 \%$ \\
\hline \multirow[t]{4}{*}{ Age } & $20-30$ & 50 & $27.0 \%$ \\
\hline & $21-40$ & 48 & $25.9 \%$ \\
\hline & $41-50$ & 42 & $22.7 \%$ \\
\hline & Above 50 & 45 & $24.3 \%$ \\
\hline \multirow[t]{2}{*}{ Job category } & Administration/ sales & 94 & $50.8 \%$ \\
\hline & Technical/ engineering & 91 & $49.2 \%$ \\
\hline \multirow{6}{*}{$\begin{array}{l}\text { Organisation } \\
\text { industry }\end{array}$} & Traditional manufacturing & 39 & $21.1 \%$ \\
\hline & High-tech manufacturing & 18 & $9.7 \%$ \\
\hline & Financial services & 72 & $38.9 \%$ \\
\hline & Government & 23 & $12.4 \%$ \\
\hline & General services & 28 & $15.2 \%$ \\
\hline & Others & 5 & $2.7 \%$ \\
\hline \multicolumn{2}{|l|}{ Total number } & 185 & $100 \%$ \\
\hline
\end{tabular}

The average level of use of e-learning systems by respondents was about five (5.02) on a 7-point Likert scale (Table 2). The results indicate that these respondents had experience in using e-learning systems in workplaces and were valid respondents for this study. Most of the respondents indicated that they used e-learning systems providing courses on job information (63.2\%); others used e-learning systems providing courses about job technology $(23.8 \%)$, a general introduction to the job $(9.2 \%)$, or language $(3.8 \%)$. Data on the purposes for using e-learning systems is presented in Table 3.

Table 2: Respondents' use of e-learning systems (7-point Likert scale; $\mathrm{N}=185$ )

\begin{tabular}{|l|c|c|}
\hline \multicolumn{1}{|c|}{ Response } & Frequency & Percent \\
\hline 1 Totally disagree & 0 & $0.0 \%$ \\
\hline 2 Disagree & 6 & $3.2 \%$ \\
\hline 3 Slightly disagree & 9 & $4.9 \%$ \\
\hline 4 & 45 & $24.3 \%$ \\
\hline 5 Slightly agree & 58 & $31.4 \%$ \\
\hline 6 Agree & 50 & $27.0 \%$ \\
\hline 7 Totally agree & 17 & $9.2 \%$ \\
\hline
\end{tabular}


Table 3: Respondents' purposes for using e-learning systems ( $\mathrm{N}=185)$

\begin{tabular}{|l|c|c|}
\hline \multicolumn{1}{|c|}{ Purpose } & Frequency & Percent \\
\hline Job knowledge & 117 & $63.2 \%$ \\
\hline Job general introduction & 17 & $9.2 \%$ \\
\hline Job technology & 44 & $23.8 \%$ \\
\hline Language & 7 & $3.8 \%$ \\
\hline
\end{tabular}

\section{Data analysis}

Having a limited sample size, PLS (partial least square) was adopted for data analysis as it was less demanding on sample size (Beaton, Lings \& Gudergan, 2008; Hsieh, Rai \& Keil, 2008). PLS is a commonly accepted data analysis method. It adopts the bootstrapping technique for re-sampling, and the partial least square method for coefficient estimation (Chin, 1998; Gefen, Straub \& Boudreau, 2000). The sample size compared to the largest path number in research model should be at least five to ten times larger (Chin, 1997; Majchrzak, Malhotra \& John, 2005). The sample size of this study was one hundred and eighty-five and the largest path number of the model was eleven. Therefore, it was adequate to adopt PLS for data analysis.

This study adopted SmartPLS 2.0 for data analysis (Ringle, 2005). The measurement and structural models were both evaluated, and each construct was modeled to be reflective in data analysis.

\section{Convergent validity and discriminate validity}

Convergent validity and discriminate validity were first provided to verify construct measures (Komiak \& Benbasat, 2006). Cronbach's alpha and the underlying factor structure were also justified.

\section{Convergent validity}

Convergent validity refers to the consistency with which multiple items measure the same construct. Unidimensionality, the average variance extracted (AVE), and the composite reliability (CR) are adequate indicators in understanding convergent validity of measurements (Bagozzi \& Yi, 1988; Steenkamp \& Van Trijp, 1991). They, as well as Cronbach's alpha, were provided in this study.

About unidimensionality, factor loading $(>0.5)$ and $t$-value $(>1.96)$ of items were both required. The results of factor loading, as well as AVE, CR and Cronbach's alpha, are given in Table 4 . The results showed that all the constructs had AVE values higher than 0.5, and all CR values were higher than 0.7 (Chin, 1998; Fornell \& Larcker, 1981; Hair, Babin, Money \& Samouel, 2003). All question items had acceptable loadings $(>0.5)$ and $t$-value $(>1.96)$. The results showed the commonly acceptable convergent validity of the measurements. Besides, all Cronbach's alpha values were also higher than 0.7 , and showed the reliability of all measurements.

\section{Discriminant validity}

In measuring discriminant validity, average variance extracted (AVE) and crossloading could be adopted to understand discriminant validity (Kerlinger \& Lee, 2000). The correlation between different constructs should be lower than the square root of the variance extracted from the individual construct (Chin, 1998; Fornell \& Larcker, 1981). In addition, the factor loadings belonging to the same construct should be 
higher than those of different constructs (Chin, 1998). The results of the AVEs are shown in Table 5. They showed that the square roots of the AVEs of all constructs were higher than their correlation coefficients with other constructs. The results of factor loadings are shown in Appendix B. They showed that each item loaded higher on its principal construct than on other constructs. Overall, the results suggested good measurement properties.

Table 4: Average variance extracted (AVE), composite reliability (CR),

Cronbach's alpha, and factor loading/weight of construct measurement

\begin{tabular}{|c|c|c|c|c|c|c|c|c|c|c|c|c|c|c|}
\hline \multicolumn{2}{|c|}{ Constructs } & AVE & CR & alpha & $\mathrm{IQ}$ & SQ & PU & US & PA & LA & $\mathrm{IO}$ & USE & $\mathrm{TP}$ & t-value \\
\hline \multirow{5}{*}{$\begin{array}{l}\text { Information } \\
\text { quality (IQ) }\end{array}$} & IQ1 & \multirow[t]{5}{*}{0.66} & \multirow[t]{5}{*}{0.91} & \multirow[t]{5}{*}{0.87} & 0.82 & & & & & & & & & 28.48 \\
\hline & IQ2 & & & & 0.84 & & & & & & & & & 27.20 \\
\hline & IQ3 & & & & 0.84 & & & & & & & & & 34.95 \\
\hline & IQ4 & & & & 0.84 & & & & & & & & & 38.56 \\
\hline & IQ5 & & & & 0.72 & & & & & & & & & 18.19 \\
\hline \multirow{4}{*}{$\begin{array}{l}\text { System } \\
\text { quality (SQ) }\end{array}$} & SQ1 & \multirow[t]{4}{*}{0.72} & \multirow[t]{4}{*}{0.91} & \multirow[t]{4}{*}{0.87} & & 0.87 & & & & & & & & 36.63 \\
\hline & SQ2 & & & & & 0.85 & & & & & & & & 34.76 \\
\hline & SQ3 & & & & & 0.85 & & & & & & & & 41.12 \\
\hline & SQ4 & & & & & 0.83 & & & & & & & & 27.92 \\
\hline \multirow{3}{*}{$\begin{array}{l}\text { Perceived } \\
\text { usefulness } \\
(\mathrm{PU})\end{array}$} & PU1 & \multirow[t]{3}{*}{\begin{tabular}{|l|}
0.80 \\
\end{tabular}} & \multirow[t]{3}{*}{0.92} & \multirow[t]{3}{*}{0.88} & & & 0.88 & & & & & & & 28.18 \\
\hline & PU2 & & & & & & 0.87 & & & & & & & 40.97 \\
\hline & PU3 & & & & & & 0.93 & & & & & & & 75.71 \\
\hline \multirow{2}{*}{$\begin{array}{l}\text { User satisf- } \\
\text { action (US) }\end{array}$} & US1 & \multirow[t]{2}{*}{0.86} & \multirow[t]{2}{*}{0.92} & \multirow[t]{2}{*}{0.84} & & & & 0.93 & & & & & & 92.91 \\
\hline & US2 & & & & & & & 0.92 & & & & & & 56.34 \\
\hline \multirow{3}{*}{$\begin{array}{l}\text { Profession } \\
\text { advance- } \\
\text { ment (PA) }\end{array}$} & PA1 & \multirow[t]{3}{*}{0.79} & \multirow[t]{3}{*}{0.92} & \multirow[t]{3}{*}{0.87} & & & & & 0.89 & & & & & 36.87 \\
\hline & PA2 & & & & & & & & 0.89 & & & & & 41.71 \\
\hline & PA3 & & & & & & & & 0.88 & & & & & 40.67 \\
\hline \multirow{3}{*}{$\begin{array}{l}\text { Learning } \\
\text { achieve- } \\
\text { ment (LA) }\end{array}$} & LA1 & \multirow[t]{3}{*}{\begin{tabular}{|l|}
0.85 \\
\end{tabular}} & \multirow[t]{3}{*}{0.94} & \multirow[t]{3}{*}{0.91} & & & & & & 0.93 & & & & 76.00 \\
\hline & LA2 & & & & & & & & & 0.92 & & & & 60.44 \\
\hline & LA3 & & & & & & & & & 0.91 & & & & 54.63 \\
\hline \multirow{3}{*}{$\begin{array}{l}\text { Influence of } \\
\text { others (IO) }\end{array}$} & IO1 & 0.71 & 0.88 & 0.79 & & & & & & & 0.75 & & & 17.86 \\
\hline & IO2 & & & & & & & & & & 0.86 & & & 29.05 \\
\hline & IO3 & & & & & & & & & & 0.91 & & & 53.83 \\
\hline Use (USE) & USE1 & 0.86 & 0.95 & 0.92 & & & & & & & & 0.93 & & 72.64 \\
\hline & USE2 & & & & & & & & & & & 0.94 & & 93.21 \\
\hline & USE3 & & & & & & & & & & & 0.92 & & 75.99 \\
\hline Task perf- & TP1 & 0.71 & 0.91 & 0.87 & & & & & & & & & 0.75 & 14.90 \\
\hline ormance & TP2 & & & & & & & & & & & & 0.88 & 33.16 \\
\hline (TP) & TP3 & & & & & & & & & & & & 0.83 & 26.43 \\
\hline & TP4 & & & & & & & & & & & & 0.92 & 71.93 \\
\hline
\end{tabular}

Table 5: Construct correlations and square root of average variance extracted (AVE)

\begin{tabular}{|c|c|c|c|c|c|c|c|c|c|}
\hline Const. & IQ & SQ & PU & US & PA & LA & IO & USE & TP \\
\hline IQ & $0.81 \mathrm{a}$ & & & & & & & & \\
\hline SQ & 0.66 & $0.85 \mathrm{a}$ & & & & & & & \\
\hline PU & 0.65 & 0.59 & $0.89 \mathrm{a}$ & & & & & & \\
\hline US & 0.65 & 0.64 & 0.69 & $0.93 \mathrm{a}$ & & & & & \\
\hline PA & 0.50 & 0.45 & 0.53 & 0.45 & $0.89 \mathrm{a}$ & & & & \\
\hline LA & 0.52 & 0.48 & 0.60 & 0.59 & 0.57 & $0.92 \mathrm{a}$ & & & \\
\hline IO & 0.41 & 0.45 & 0.56 & 0.50 & 0.59 & 0.61 & $0.84 \mathrm{a}$ & & \\
\hline USE & 0.53 & 0.56 & 0.67 & 0.60 & 0.47 & 0.56 & 0.57 & $0.93 \mathrm{a}$ & \\
\hline TP & 0.58 & 0.55 & 0.69 & 0.58 & 0.65 & 0.65 & 0.60 & 0.64 & $0.85 \mathrm{a}$ \\
\hline
\end{tabular}

a: Indicates the square root of average variance extracted (AVE) of the construct. 


\section{Path analysis}

With adequate convergent and discriminant validity, the hypotheses were then empirically tested. However, learning motivation was composed of the sub-constructs of professional advancement, learning achievement and the influence of others; it was thus measured by the repeating indicators from the first-order constructs (Diamantopoulos, Riefler \& Roth, 2008; Wiley, 2005). The results of the SmartPLS analysis are shown in Figure 3. The results indicated that excluding H1c, all other hypotheses were supported.

The results showed that employees' use of e-learning systems had a significantly positive association with their self-evaluation task performance; thus, H3 was accepted. The results indicated that employees gained beneficial consequences from their use of the systems in performing tasks. Besides, perceived usefulness and user satisfaction were shown to have significant influence on system usage, and perceived usefulness had significant impact on user satisfaction. Therefore, H2a, H2b, and $\mathrm{H} 2 \mathrm{c}$ were accepted. Furthermore, learning motivation was shown to have a significant influence on not only perceived usefulness and user satisfaction, but also system usage. Therefore, H4a, H4b, and H5 were accepted. Finally, perceived usefulness was shown to be influenced by information quality, but not by system quality, and user satisfaction was significantly influenced by both information and system qualities. Thus, H1a, H1b, and H1d were accepted, while H1c was rejected.

The results empirically validated the impact of other supposed net benefits to individuals, organisations, or society in the IS success model. They showed employees' learning motivation, reflecting their learning needs strengths in acting to meet the needs, increased their motivation for e-learning systems use, i.e. perceived usefulness and user satisfaction. Use of the systems enhanced their task performance, something sought by organisations. The validation indicated the alignment of e-learning systems with organisational goals, indicated by employees' task performance, and employees' individual learning needs, indicated by the strengths of their learning motivation.

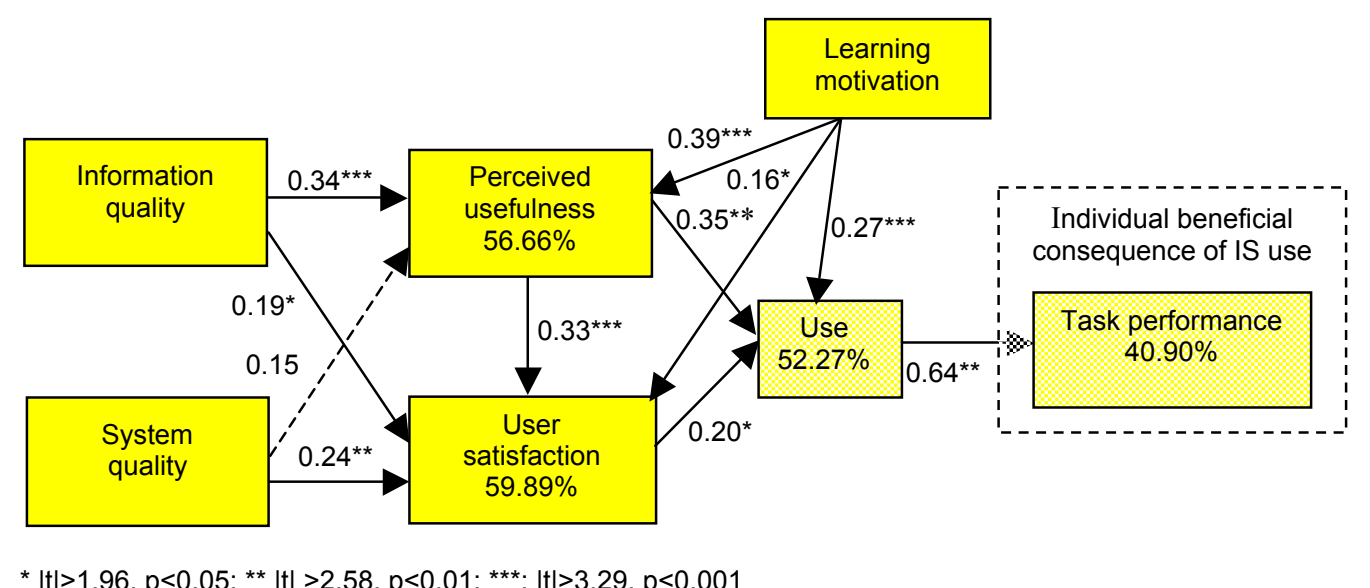

Figure 3: The PLS results 
However, to further understand the impact of the different learning motivation subconstructs in employees' use of e-learning systems, a first-order PLS analysis of the sub-construct path model based on the proposed hypotheses was also made for additional justification. The sample size compared to the largest path number of the sub-construct path model still conformed to the suggestions of Chin (1997) and Majcherzak et al. (2005). Results of the further analysis are shown in Appendix B.

Most of the results in Appendix B were consistent with Figure 3 results. Nevertheless, the different learning motivation orientations/sub-constructs presented different impacts. First of all, the learning achievement sub-construct was shown to have significant impact on perceived usefulness and user satisfaction, but not on system usage. Secondly, the sub-construct of the influence of others showed its significant impact on perceived usefulness and system usage, but not on user satisfaction. Nevertheless, the professional advancement sub-construct did not show any significant impact on system usage, perceived usefulness or user satisfaction.

The results indicated that employees who used e-learning systems did not use the systems for their current advancement of jobs. On the contrary, they used the systems because of the influence of others. Besides, their intrinsic learning achievement also affected their system use, whereby the impact was mediated through their perceived usefulness and user satisfaction of the systems.

\section{Discussion}

Most current studies focus on the technical issues of e-learning development, which is confronted with complex set of factors. It was not clear the alignment of employees' learning needs and organisational goals in e-learning training. Based on the IS success model, this study clarifies the impact of learning motivation upon e-learning systems use for employee productivity. The results indicated the importance of learning motivation in employees' self-directed, autonomous e-learning training.

Capture both the technological and human dimensions for e-learning system use

E-learning systems were designed for learning/training, and training transfer will not occur if users were not motivated to use the systems. The results showed the significant positive association of employees' perception of technological quality, information quality and system quality, with their perceived motivation for e-learning systems use, perceived usefulness and user satisfaction that motivated them. This reflected the importance of both the technological and human dimensions for employees' use of e-learning systems.

Revalidate the association of employees' e-learning systems use with job-related performance In the changed learning/training environment, employees' acceptance or use of elearning systems was important to organisations which have adopted e-learning systems for human capital management. The results showed that employees' use of elearning systems improved their task performance, indicating that employees gained beneficial consequences through e-learning and transferred what they gained through the training to their tasks.

Learning motivation for e-learning system use

Finally, the results empirically clarified employees' learning motivation increased perceived usefulness and user satisfaction for e-learning, and also increased their use of the systems. The analysis further specified employees' learning motivations for e- 
learning training. Although professional advancement did not show its impact, the influence of other persons and intrinsic learning achievements both directly or indirectly helped employees' acceptance and use of e-learning. This will help in the designinf of e-learning for employees' self-directed learning in workplaces.

\section{Conclusion}

Learning motivation indicated employees' readiness, capacity and willingness to take charge of their learning to meet their needs and goals (Holec, 1981; Dam, 1995). For learning occurrences, providing for general principles in an suitable context to meet the learners' inner psychological structure helped them to apply what they learned to new problems (Gredler, 1992; Bandura, 1977; Griffin \& Griffin, 1996; Roblyer, 2004). Elearning systems provided only a potential stimulus to kindle learners' acquisition of knowledge. With high learning motivation, employees took responsibility for learning, and meaningful learning occurred and improved learning outcomes from e-learning training (Dam, 1995).

The results indicated the alignment of e-learning systems with organisational goals, in the form of employees' task performance and employees' individual learning needs, by relying on strengths in their learning motivation. This validation will help facilitate the design of e-learning for employees' self-directed learning in workplaces (Cross, 1982; Houle, 1979; Rubenson, 1991). The results also validated the impact of other supposed net benefits to individuals, organisations, or society in the IS success model. Practically, the results will help organisations' human capital management through the investment of e- learning systems for employee training, and theoretically, the clarification facilitates the further advancement of the IS success model.

\section{Limitations and suggestions}

The validation of the impact of learning motivation upon employees' use of e-learning systems cannot not be established on the basis of a single empirical study. Hence, we need to be cautious when generalising from the findings. For example, samples from different contexts or diverse working conditions could be studied to revalidate the perceptual connection. In addition, the impact of other important factors regarding elearning, such as group support or organisational culture, facilitating conditions (e.g. reward), and different demographic characteristics, also could to be clarified in the context of workplace e-learning.

\section{Acknowledgments}

The author would like to thank the Editor, Dr Roger Atkinson, and anonymous reviewers for their valuable comments to improve this paper.

\section{References}

Bagozzi, R. P. \& Yi, Y. (1988). On the evaluation of structural equation models. Journal of the Academy of Marketing Science, 16(1), 74-94. http:/ / dx.doi.org/10.1177/009207038801600107

Bandura, A. (1977). Social learning theory. Englewood Cliffs, NJ: Prentice-Hall.

Beaton, A., Lings, I. N. \& Gudergan, S. (2008). Service staff attitudes, organisational practices and performance drivers. Journal of Management $\mathcal{E}$ Organisation, 14, 168-179. http:/ /jmo.econtentmanagement.com/archives/vol/14/issue/2/article/2265/ 
Blake, M. B. \& Butcher-Green, J. D. (2009). Agent-customized training for human learning performance enhancement. Computers $\mathcal{E}$ Education, 53(3), 966-976. http: / / dx.doi.org/10.1016/j.compedu.2009.05.014

Borman, W. C. \& Motowidlo, S. J. (1993). Expanding the criterion domain to include elements of contextual performance. In N. Schmitt \& W. C. Borman (Eds), Personnel selection in organisations (pp.71-98). San Francisco: Jossey-Bass.

Boshier, R. (1978). Education participation scale factors structure for older adults. Adults Education, 28(3), 165-175.

Campbell, J. P., Dunnette, M. D., Lawler, E. E. \& Weick, K. E. (1970). Managerial behavior, performance, and effectiveness. NY: McGraw-Hill.

Chen, H. J. (2010). Linking employees' e-learning system use to their overall job outcomes: An empirical study based on the IS success model. Computers $\mathcal{E}$ Education, 55(4), 1628-1639. http: / / dx.doi.org/10.1016/j.compedu.2010.07.005

Chen, H. J. (2012). Clarifying the empirical connection of new entrants' e-learning systems use to their job adaptation and their use patterns under the collective-individual training environment. Computers \& Education, 58(1), 321-337. http: / / dx.doi.org/10.1016/j.compedu.2011.07.010

Chen, P. S. \& Chih, J. T. (2011). The relations between learner motivation and satisfaction with management training: An empirical study in Taiwan. International Journal of Management, 28(1), 77-91. http:/ / www.internationaljournalofmanagement.co.uk/2011/2011-1.html\#a6

Chin, W. W. (1997). Overview of the PLS method. [verified 17 Apr 2012] http: / / disc-nt.cba.uh.edu/chin/ PLSINTRO.HTM

Chin, W. W. (1998). The partial least squares approach to structural equation modeling. In G. A. Marcoulides (Ed), Modern methods for business research (pp. 295-336), Mahwah, New Jersey: Lawrence Erlbaum Associates.

Collin, K. (2006). Connecting work and learning: Design engineers' learning at work. Journal of Workplace Learning, 18(7/8), 403-413. http:/ / dx.doi.org/10.1108/13665620610692971

Cross, K. P. (1982). Adults learners: Increasing participation and facilitating learning. San Francisco, CA: Jossey-Bass Press.

Dam, L. (1995). Learner autonomy 3: From theory to practice. Dublin: Authentik.

Davis, F. D., Bagozzi, R.P . \& Warshaw, P. R. (1992). Extrinsic and intrinsic motivation to use computers in the workplace. Journal of Applied Social Psychology, 22, 1111-1132. http: / / dx.doi.org/10.1111/j.1559-1816.1992.tb00945.x

DeLone, W. H. \& McLean, E. R. (1992). Information systems success: The quest for the dependent variable. Information Systems Research, 3(1), 60-95. http: / / dx.doi.org/10.1287/ isre.3.1.60

DeLone, W. H. \& McLean E. R. (2003). Model of information system success: A ten-year update. Journal of Management Information Systems, 19(4), 9-30. [verified 17 Apr 2012; abstract only] http: / / www.jmis-web.org/articles/v19_n4_p9/index.html

Diamantopoulos, A., Riefler, P. \& Roth, K. P. (2008). Advancing formative measurement models. Journal of Business Research, 61(12), 1203-1218. http:/ / dx.doi.org/10.1016/j.jbusres.2008.01.009

Eggen, P. \& Kauchak, D. (1994). Educational psychology: Classroom connections. New York: Macmillan College Publishing Company.

Fornell, C. \& Larcker, D. F. (1981). Evaluating structural equation models with unobservable variables and measurement errors. Journal of Marketing Research, 18(1), 39-50.

Fraser, S. G. \& Salter, G. (1995). A motivational view of information system success: A reinterpretation of Delone and Mclean's Model, Working Paper, Department of Accounting and Finance. The University of Melbourne, Australia. 
Gefen, D., Straub, D. W. \& Boudreau, M. C. (2000). Structural equation modeling and regression: Guidelines for research practice. Communications of the Association for Information Systems, 4(7), 2-77. [verified 17 Apr 2012] http: / / aisel.aisnet.org / cgi/ viewcontent.cgi?article=2531\&context=cais

Gredler, M. E. (1992). Learning and instruction: Theory into practice. Free Press, 2nd edition.

Griffin, M. M. \& Griffin, B. W. (1996). Situated cognition and cognitive style: Effects on students' learning as measured by conventional tests and performance assessments. Journal of Experimental Education, 64(4), 293-308.

Hair, J. F., Babin, B., Money, A. H. \& Samouel, P. (2003). Essentials of business research methods. John Wiley \& Sons, Inc.

Holec, H. (1981). Autonomy in foreign language learning. Oxford: Pergamon.

Houle, C. O. (1979). Motivation and participation with special reference to non-traditional forms of study. In OECD Learning opportunity for adults, Vol. III, The non-participation issue. Paris: $\mathrm{OECD}, 8-34$

Hsieh, J. J., Rai, A. \& Keil, M. (2008). Understanding digital inequality: Comparing continued use behavior models of the socio-economically advantaged and disadvantaged. MIS Quarterly, 32(1), 97-126. http: / / misq.org/ understanding-digital-inequality-comparing-continued-usebehavioral-models-of-the-socio-economically-advantaged-and-disadvantaged.html

Kao, C.-H. (2009). Clarifying the impact of learning motivation on staff's system benefits of e-learning system use from the perspective of IS success model. Thesis, I-Shou University, Taiwan.

Kerlinger, F. N. \& Lee, H. B. (2000). Foundations of behavioral research (4th ed.). Wadsworth.

Kirkpatrick, D.L. (1994). Evaluating training programs. San Francisco, CA: Berrett-Koehler Publishers.

Kirkpatrick, D. (1996). Great ideas revisited: Revisiting Kirkpatrick's four-level model. Training $\mathcal{E}$ Development, 50(1), 54-57.

Komiak, S. Y. X. \& Benbasat, I. (2006). The effects of personalization and familiarity on trust and adoption of recommendation agents. MIS Quarterly, 30(4), 941-960. http: / / aisel.aisnet.org/misq/vol30/iss4/9/

Lee, B. C., Yoon, J. O. \& Lee, I. (2009). Learners' acceptance of e-learning in South Korea: Theories and results. Computers $\mathcal{E}$ Education, 53(4), 1320-1329. http: / / dx.doi.org/10.1016/j.compedu.2009.06.014

Majchrzak, A., Beath, C. M., Lim, R. \& Chin, W. W. (2005). Management client dialogues during information systems design to facilitate client learning. MIS Quarterly, 29(4), 653-672. http: / / misq.org/managing-client-dialogues-during-information-systems-design-tofacilitate-client-learning.html

Markus, H. \& Wurf, E. (1987). The dynamic self-concept: A social psychological perspective. Annual Review of Psychology, (38), 299-337. http: / / dx.doi.org/10.1146/ annurev.ps.38.020187.001503

Morstain, B. R. \& Smart, J. C. (1974). Reasons for participation in adult education courses: A multivariate analysis of group differences. Adult Education Quarterly, 24(2), 83-98. http: / / dx.doi.org/10.1177/074171367402400201

Newton, R. \& Doonga, N. (2007). Corporate e-learning: Justification for implementation and evaluation of benefits. A study examining the views of training managers and training providers. Education for Information, 25(2), 111-130. http: / / iospress.metapress.com/ content /h63470250750p25g/ ?p=7568b1dea9b9411db3a65b60a9031b9a\&pi=2

Pintrich, P. R. (1987). Motivation and learning strategies in the college classroom. Paper presented at the American Educational Research Association Convention. Washington, DC. 
Pintrich, P. R. \& DeGroot, E. V. (1990). Motivational and self-regulated learning components of classroom academic performance. Journal of Educational Psychology, 82(1), 33-40. http: / psycnet.apa.org/journals/edu/82/1/

Pintrich, P. R. \& Schunk, D. H. (2002). Motivation in education: Theory, research, and applications. Upper Saddle River. NJ: Merrill Prentice-Hall.

Rai, A., Lang, S. S. \& Welker, R. B. (2002). Assessing the validity of IS success models: An empirical test and theoretical analysis. Information Systems Research, 13(1), 50-69. http: / / dx.doi.org/10.1287/ isre.13.1.50.96

Ringle, C. M., Wende, S. \& Will, S. (2005). SmartPLS 2.0 (M3) Beta. Hamburg, http: / / www.smartpls.de /

Roblyer, M. D. (2004). Educational technology in action. Pearson/Merrill Prentice Hall.

Rosenberg, M. J. (2006). Beyond e-learning: approaches and technologies to enhance organizational knowledge, learning, and performance. San Francisco: Pfeiffer.

Rubenson, K. (1979). Recruitment to adult education in the Nordic countries: Research and outreaching activities. Sweden: Stockholm Inst of Education.

Rubenson, K. (1991). Educational leave and study assistance in Sweden. In Abrahamsson, K. \& Henriksson, K. (Ed), New challenges in the education and training of the European workforce: Presentations (pp. 103-132). Stockholm: Ministry of Education.

Schunk, D. H. \& Zimmerman, B. J. (1994). Self-regulation of learning and performance. Hillsdale, NJ: Lawrence Erlbaum Associates.

Seddon, P. B. (1997). A respecification and extension of the DeLone and McLean Model of IS success. Information Systems Research, 8(3), 240-253. http: / / dx.doi.org/10.1287/ isre.8.3.240

Seddon, P. B. \& Kiew, M. Y. (1996). A partial test and development of DeLone and Mclean's model of IS success. Australian Journal of Information Systems, 4(1), 90-109. http:/ / dl.acs.org.au/index.php/ajis/article/view/379

Shore, L. M. \& Thornton III, G. C. (1986). Effects of gender on self- and supervisory ratings. Academy of Management Journal, 29(1), 115-129. http: / / www.jstor.org/stable/ 255863

Slavin, R. E. (1994). Educational psychology: Theory and practice. Boston: Allyn \& Bacon.

Steenkamp, J. E. M. \& Van Trijp, H. C. M. (1991). The use of LISREL in validating marketing constructs. International Journal of Research in Marketing, 8(4), 283-299. http: / / dx.doi.org/ 10.1016/0167-8116(91)90027-5

Tempelaar, D. T., Gijselaers, W. H., Van de Loeff, S. S. \& Nijhuis, J. F. H. (2007). A structural equation model analyzing the relationship of student achievement motivations and personality factors in a range of academic subject-matter areas. Contemporary Educational Psychology, 32(1), 105-131. http: / / dx.doi.org/10.1016/j.cedpsych.2006.10.004

Tsai, C. C., Shih, M. \& Feng, J. (2008). Research and trends in the field of e-learning from 2001 to 2005: A content analysis of cognitive studies in selected journals. Computers $\mathcal{E}$ Education, 51(2), 955- 967. http:/ / dx.doi.org/10.1016/j.compedu.2007.10.004

Venkatesh, V. (2000). Determinants of perceived ease of use: Integrating control, intrinsic motivation, and emotion into the technology acceptance model. Information System Research, 11(4), 342-365. http: / / dx.doi.org/10.1287/isre.11.4.342.11872

Wang, M. (2011). Integrating organizational, social, and individual perspectives in Web 2.0based workplace e-learning. Journal of Information Systems Frontiers, 13(2), 153-155. http: / / dx.doi.org/10.1007/ s10796-009-9191-y

Wang, M., Ran, W., Liao, J. \& Yang, S. J. H. (2010). A performance-oriented approach to elearning in the workplace. Educational Technology E Society, 13(4), 167-179. http:/ / www.ifets.info/journals/13_4/15.pdf 
Wang, Y. S., Wang, H. Y. \& Shee, D. Y. (2007). Measuring e-learning systems success in an organizational context: Scale development and validation. Computers in Human Behavior, 23(4), 1792-1808. http: / /dx.doi.org/10.1016/j.chb.2005.10.006

Wexley, K. N. \& Latham, G. P. (1981). Developing and training human resources in organisations. IL: Scott, Foresman.

Whitfield, K. (2000). High-performance workplace, training, and the distribution of skills. Industrial Relations, 39(1), 1-25. http: / / dx.doi.org/10.1111 / 0019-8676.00150

Wiley, J. B. (2005). Reflections on formative measures: Conceptualization and implication for use. ANZMAC 2005 Conference: Marketing Research and Research Methodologies (Quantitative), Perth: 5-7 Dec. 2005.

Wu, J. H. \& Wang, Y. M. (2006). Measuring KMS success: A respecification of the DeLone and McLean's model. Information \& Management, 43(6), 728-739. http: / / dx.doi.org/10.1016/j.im.2006.05.002

\section{Appendix A: Construct measures}

\begin{tabular}{|c|c|c|c|}
\hline \multirow{2}{*}{\multicolumn{2}{|c|}{$\begin{array}{r}\text { Constructs } \\
\text { Information quality }\end{array}$}} & \multicolumn{2}{|r|}{ Measurements } \\
\hline & & IQ1 & $\begin{array}{l}\text { The e-learning system provides sufficient and complete } \\
\text { information. }\end{array}$ \\
\hline & & IQ2 & The e-learning system provides clear and definite information. \\
\hline & & IQ3 & $\begin{array}{l}\text { The information provided by the e-learning system meets my } \\
\text { needs. }\end{array}$ \\
\hline & & IQ4 & $\begin{array}{l}\text { The information provided by the e-learning system helps to } \\
\text { solve my problems. }\end{array}$ \\
\hline & & IQ5 & The content of the e-learning system is good. \\
\hline System quality & & SQ1 & The e-learning system provides interfaces of easy operation. \\
\hline & & SQ2 & $\begin{array}{l}\text { The buttons for operation of the e-learning system are clearly } \\
\text { and easily understood. }\end{array}$ \\
\hline & & SQ3 & The e-learning system responses instantly. \\
\hline & & SQ4 & $\begin{array}{l}\text { The functions of the e-learning system work well and are } \\
\text { seldom out of use. }\end{array}$ \\
\hline Perceived usef & fulness & PU1 & Using the e-learning system enhances my work efficiency. \\
\hline & & PU2 & $\begin{array}{l}\text { Using the e-learning system increases my competing } \\
\text { competence. }\end{array}$ \\
\hline & & PU3 & Using the e-learning system enhances my work productivity. \\
\hline User satisfacti & & US1 & $\begin{array}{l}\text { The sufficient information of the e-learning system that meets } \\
\text { my work needs is satisfying. }\end{array}$ \\
\hline & & US2 & The efficiency of the e-learning system is satisfying. \\
\hline Learning & Profession & PA1 & To increase work capabilities. \\
\hline motivation & advancement & PA2 & Due to work needs. \\
\hline for e-learning & (PA) & PA3 & Because of changes in the job. \\
\hline systems & Learning & LA1 & Satisfied with the substantial feeling due to learning. \\
\hline & achievement & LA2 & Interested in the training content. \\
\hline & (LA) & LA3 & Learning makes me feel sense of achievement. \\
\hline & $\begin{array}{l}\text { Influence of } \\
\text { others (IO) }\end{array}$ & IO1 & $\begin{array}{l}\text { Because of the influence other people who undertake the } \\
\text { learning. }\end{array}$ \\
\hline & & $\mathrm{IO} 2$ & For the reason that people tell me the benefits of learning. \\
\hline & & IO3 & To catch up with others. \\
\hline Use (USE) & & U1 & I frequently use the e-learning system. \\
\hline & & $\mathrm{U} 2$ & I use lots of functions of the e-learning system. \\
\hline & & U3 & I depend on the e-learning system. \\
\hline
\end{tabular}




\begin{tabular}{|l|l|l|}
\hline $\begin{array}{l}\text { Perceived beneficial } \\
\text { consequences of IS use: } \\
\text { Task performance }\end{array}$ & TP1 & $\begin{array}{l}\text { I accomplish tasks according to standard operation } \\
\text { procedures. }\end{array}$ \\
\cline { 2 - 3 } & TP2 & $\begin{array}{l}\text { After use of the e-learning systems, my work efficiency is } \\
\text { better than my other colleagues. }\end{array}$ \\
\cline { 2 - 3 } TP3 & $\begin{array}{l}\text { I know how to plan and schedule the rate of progress of the } \\
\text { tasks that I am responsible for. }\end{array}$ \\
\cline { 2 - 3 } & TP4 & $\begin{array}{l}\text { After use of the e-learning system, my average work efficiency } \\
\text { enhances. }\end{array}$ \\
\hline
\end{tabular}

\section{Appendix B: Cross loadings}

\begin{tabular}{|c|c|c|c|c|c|c|c|c|c|}
\hline Items & IQ & SQ & PU & US & PA & LA & $\mathrm{IO}$ & USE & $\mathrm{TP}$ \\
\hline IQ1 & 0.82 & 0.51 & 0.46 & 0.48 & 0.43 & 0.39 & 0.33 & 0.36 & 0.44 \\
\hline IQ2 & 0.84 & 0.51 & 0.42 & 0.47 & 0.30 & 0.39 & 0.24 & 0.33 & 0.38 \\
\hline IQ3 & 0.84 & 0.56 & 0.54 & 0.51 & 0.46 & 0.38 & 0.27 & 0.41 & 0.44 \\
\hline IQ4 & 0.84 & 0.55 & 0.62 & 0.57 & 0.42 & 0.41 & 0.33 & 0.43 & 0.44 \\
\hline IQ5 & 0.72 & 0.53 & 0.56 & 0.56 & 0.40 & 0.53 & 0.47 & 0.58 & 0.63 \\
\hline SQ1 & 0.58 & 0.87 & 0.44 & 0.53 & 0.39 & 0.35 & 0.37 & 0.45 & 0.42 \\
\hline SQ2 & 0.59 & 0.85 & 0.50 & 0.56 & 0.41 & 0.41 & 0.40 & 0.49 & 0.49 \\
\hline SQ3 & 0.54 & 0.85 & 0.53 & 0.57 & 0.38 & 0.43 & 0.36 & 0.49 & 0.48 \\
\hline SQ4 & 0.52 & 0.83 & 0.51 & 0.52 & 0.36 & 0.41 & 0.40 & 0.47 & 0.49 \\
\hline PU1 & 0.54 & 0.56 & 0.88 & 0.62 & 0.45 & 0.52 & 0.44 & 0.58 & 0.61 \\
\hline PU2 & 0.58 & 0.48 & 0.87 & 0.61 & 0.45 & 0.56 & 0.55 & 0.58 & 0.56 \\
\hline PU3 & 0.63 & 0.54 & 0.93 & 0.64 & 0.53 & 0.55 & 0.51 & 0.63 & 0.66 \\
\hline US1 & 0.64 & 0.58 & 0.66 & 0.93 & 0.43 & 0.56 & 0.50 & 0.58 & 0.58 \\
\hline US2 & 0.55 & 0.62 & 0.62 & 0.92 & 0.40 & 0.53 & 0.43 & 0.53 & 0.50 \\
\hline PA1 & 0.53 & 0.40 & 0.50 & 0.43 & 0.89 & 0.56 & 0.49 & 0.41 & 0.57 \\
\hline PA2 & 0.41 & 0.39 & 0.48 & 0.40 & 0.89 & 0.52 & 0.54 & 0.39 & 0.60 \\
\hline PA3 & 0.39 & 0.41 & 0.43 & 0.37 & 0.88 & 0.44 & 0.55 & 0.47 & 0.57 \\
\hline LA1 & 0.51 & 0.44 & 0.57 & 0.54 & 0.55 & 0.93 & 0.58 & 0.52 & 0.62 \\
\hline LA2 & 0.44 & 0.43 & 0.52 & 0.52 & 0.45 & 0.92 & 0.52 & 0.52 & 0.55 \\
\hline LA3 & 0.49 & 0.45 & 0.58 & 0.56 & 0.58 & 0.91 & 0.59 & 0.50 & 0.61 \\
\hline IO1 & 0.35 & 0.32 & 0.45 & 0.34 & 0.68 & 0.53 & 0.75 & 0.45 & 0.60 \\
\hline IO2 & 0.27 & 0.38 & 0.39 & 0.43 & 0.36 & 0.48 & 0.86 & 0.42 & 0.39 \\
\hline IO3 & 0.40 & 0.43 & 0.54 & 0.49 & 0.46 & 0.54 & 0.91 & 0.55 & 0.52 \\
\hline USE1 & 0.49 & 0.55 & 0.62 & 0.57 & 0.44 & 0.53 & 0.52 & 0.93 & 0.59 \\
\hline USE2 & 0.48 & 0.51 & 0.60 & 0.55 & 0.44 & 0.51 & 0.50 & 0.94 & 0.57 \\
\hline USE3 & 0.50 & 0.51 & 0.64 & 0.56 & 0.44 & 0.51 & 0.57 & 0.92 & 0.62 \\
\hline TP1 & 0.39 & 0.36 & 0.44 & 0.41 & 0.46 & 0.40 & 0.35 & 0.39 & 0.75 \\
\hline TP2 & 0.50 & 0.54 & 0.64 & 0.58 & 0.58 & 0.57 & 0.62 & 0.65 & 0.88 \\
\hline TP3 & 0.51 & 0.49 & 0.52 & 0.39 & 0.52 & 0.56 & 0.43 & 0.45 & 0.83 \\
\hline TP4 & 0.56 & 0.46 & 0.66 & 0.55 & 0.62 & 0.63 & 0.56 & 0.60 & 0.92 \\
\hline
\end{tabular}

Authors: Dr Hsiu-Ju Chen, Assistant Professor, Department of Information Management, I-Shou University, Taiwan.

Email: hjchen@isu.edu.tw Web: http: / / www.mis.isu.edu.tw/ site/mis

Chia-Hung Kao, Department of Information Management, I-Shou University, Taiwan.

Please cite as: Chen, H. J. \& Kao, C. H. (2012). Empirical validation of the importance of employees' learning motivation for workplace e-learning in Taiwanese organisations. Australasian Journal of Educational Technology, 28(4), 580-598. http: / / www.ascilite.org.au/ajet/ajet28/chen-hj.html 